\title{
Effectiveness of BPMC Application against Bemisia tabaci (Gennadius) Population and CMMV Disease Incidence on Soybean
}

\author{
WARTONO*, I WAYAN LABA AND WAWAN \\ Indonesian Center for Agricultural Biotechnology and Genetic \\ Resources Research and Development \\ Jalan Tentara Pelajar No.3A, Bogor 16111 \\ (received April 2011, accepted August 2011)
}

\begin{abstract}
ABSTRAK
Pengaruh Aplikasi BPMC terhadap Populasi Bemisia tabaci (Gennadius) dan Kejadian Penyakit CMMV pada Tanaman Kedelai. Pengendalian hama kutu putih (Bemisia tabaci (Gennadius)) adalah titik awal dalam menekan penyakit CMMV (Cowpea mild mottle virus). Penelitian bertujuan untuk mengetahui pengaruh aplikasi BPMC (500 g b.a./l) terhadap populasi B. tabaci dan kejadian penyakit CMMV pada tanaman kedelai. Penelitian dilakukan dalam skala lapangan dengan rancangan acak kelompok yang terdiri dari 5 perlakuan yaitu lima tingkat konsentrasi: 0,$75 ; 1,50 ; 2,25$; dan 3,00 ml/l serta kontrol, dengan 5 ulangan. Hasil penelitian menunjukkan bahwa BPMC efektif dalam menekan populasi imago B. tabaci dan kejadian penyakit CMMV.
\end{abstract}

KATA KUNCI: Efikasi, kutu kebul, spesies invasif, insektisida

\begin{abstract}
Effectiveness of BPMC Application against Bemisia tabaci (Gennadius) Population and CMMV Disease Incidence on Soybean. Control of whitefly (Bemisia tabaci (Gennadius)) is the starting point in suppressing the CMMV disease (cowpea mild mottle virus). This study aims to determine the influence of applications BPMC (500 $\mathrm{g}$ a.i./l) against $B$. tabaci populations and disease incidence of CMMV on soybean plants. Research was conducted in the field with randomized complete block design consisting of 5 treatments i.e. five concentration levels: $0.75,1.50$, 2.25 , and $3.00 \mathrm{ml} / 1$ including control (untreated) with 5 replications. The results showed that BPMC is effective in suppressing the adult population of $B$. tabaci and disease incidence of CMMV.
\end{abstract}

KEY WORDS: Efficacy, whitefly, invasive species, insecticide

*Korespondensi:

Telp.: +62-251-8337975, Faks : 0251-8338820

Email: war.tono@yahoo.com 


\section{INTRODUCTION}

Soybean is one of the staple foods of Indonesian people. This is because soybean is a raw material for the manufacture of tempeh and tofu that has become a daily menu of Indonesian society in general. The national needs for soybean reached 2.2 million tons per year. However, only 20 to 30 percent of those needs can be met by domestic production; while, 70 to 80 percent of the lack, depending on imports.

In an effort to increase soybean production, pest and disease are still to be the problem. Several potential pests that may cause significant damage to crops of soybean include seed flies, caterpillars, pod sucking and pod borer pest (Harnoto et al. 1985; Harnoto et al. 1993). Some of insect pest of soybean also play an important role as a vectors of disease.

In addition to aphids, insect vectors often found on soybean is whitefly Bemisa tabaci Gennadius (Hemiptera: Aleyrodidae). The sweetpotato whitefly is a major pest of economically important crops worldwide (Gerling et al. 1980; Nomikou et al. 2000). Damage can be caused directly by feeding on phloem sap or indirectly by the large amounts of honeydew produced lowering photosynthesis. Bemisia tabaci is also a vector of many plant viruses (Alegbejo 2000: Simón et al.
2003). There are more than 110 species of virus in various host plants transmitted by this vector. One of the viruses that are transmitted by $B$. tabaci on soybean is cowpea mild mottle virus (CMMV). CMMV is very easily transmitted by $B$. tabaci in a non-persistent manner (Muniyappa \& Reddy 1982; Iwaki et al. 1983). CMMV was known to be widely spread in soybean production centers in Indonesia, in line with the increasing of viral vector population ( $B$. tabaci) in the field. In Java, CMMV was a prevalent disease (Nasir et al. 1989). CMMV disease can cause yield loss until 80\% (Saleh et al. 2004; Saleh et al. 2005), depending on variety and age at the time of infected soybean plants.

Control of B. tabaci can be done by using chemical synthetic insecticide. The use of insecticide is preferable due to its easy application and its fast effects in suppressing the target pest. However, its use must be done carefully, so as to reduce negative impacts on the environment and the occurrence of resistance. Selection of the active ingredient is also needed to know the mode of action of the active ingredient with the target pest to be controlled.

BPMC or fenobucarb is a contact insecticide that is effective in controlling caterpillar pests, trips, and aphids. All the time, this insecticide is often used to control pests on paddy. BPMC testing on other crops need to 
be done, in order to know its effectiveness against other pests.

This study was conducted to determine the effect BPMC application on population of B. tabaci and disease incidence of CMMV on soybean plants.

\section{MATERIALS AND METHODS}

The research was conducted at the experimental plantation of Citayam, Indonesian Center for Agricultural Biotechnology and Genetic Resources Research and Development (ICABIOGRAD), Bogor, West Java during growing season in 2010. Randomized block design was used consisting of 5 treatments with 5 replications. Tested insecticide was BPMC (500 g a.i./l) consisting of five levels of concentration, namely: $0.75,1.50,2.25$, and $3.00 \mathrm{ml} / \mathrm{l}$ including control (untreated).

Experimental plots size was $8 \mathrm{~m} \mathrm{x}$ $5 \mathrm{~m}$ with a spacing of $20 \mathrm{~cm} \mathrm{x} 40 \mathrm{~cm}$. Distance between plots were $40 \mathrm{~cm}$. Variety of soybean planted was Grobogan with two seeds per planting hole. Fertilization was done at the time of planting with $200 \mathrm{~kg}$ of Urea, SP-36 $150 \mathrm{~kg}$ and $150 \mathrm{~kg} \mathrm{KCl} / \mathrm{ha}$ sown around the planting hole.

Soybean plants are maintained well, watering and weeding were carried out as needed. Observation was made on 10 plants of which are determined systematically. Observations of population of B. tabaci were done by counting the imago population that was caught by the sweeping cloth. Five swings were performed using a dark colored cloth with a diameter of $20 \mathrm{~cm}$ and length of $50 \mathrm{~cm}$. CMMV disease was observed by looking at the symptoms. To define the symptom, ELISA test was conducted in the laboratory with NCM-ELISA (nitro cellulose membrane - enzyme linked immunosorbent assay) (Lazarovits et al. 1989). Antiserum CMMV was obtained from the collections of Biochemistry Research Group of ICABIOGRAD. The visual symptom of CMMV infection then was used to calculate the percentage of disease incidence based on the equation:

$$
\mathrm{DI}=\frac{\mathrm{a}}{\mathrm{a}+\mathrm{b}} \times 100
$$

$\mathrm{DI}=$ disease incidence

$\mathrm{a}=$ numbers of plant with CMMV symptoms

$\mathrm{b}=$ numbers of plant looked healthy

Insecticide application was done a day after the appearance of the target pest. Applications were made at intervals of one week to two weeks prior to harvest. Application is done by spraying using high-pressure sprayer with a sprayed volume $500-600 \mathrm{ml} / 1$ or as the result of calibration.

Data on population of $B$. tabaci and the disease incidence of CMMV were used to calculate the efficacy of the tested insecticides. If the first observation of target pest population or 
disease incidence was not significantly different between treatments, the efficacy of the tested insecticides was calculated with the formula Abbot (1925):

$\mathrm{E}=\left(\frac{\mathrm{Ca}-\mathrm{Ta}}{\mathrm{Ca}}\right) \times 100 \%$

$\mathrm{E}=\operatorname{efficacy}(\%)$

$\mathrm{Ca}=$ populations or disease incidence of control plot after insecticides application

$\mathrm{Ta}=$ populations or disease incidence of treatment plot after insecticides application

If the first observation of the population or the disease incidence was significantly different between treatments, the efficacy was calculated with the formula Henderson and Tilton (1955):

$\begin{aligned} \mathrm{E}= & \left(1-\frac{\mathrm{Ta}}{\mathrm{Ca}} \times \frac{\mathrm{Cb}}{\mathrm{Tb}}\right) \times 100 \% \\ \mathrm{E}= & \text { efficacy }(\%) \\ \mathrm{Ca}= & \text { level of crop damage of the } \\ & \text { control plot after insecticide } \\ & \text { application } \\ \mathrm{Cb}= & \text { level of crop damage of the } \\ & \text { control plot before insecticide } \\ & \text { application } \\ \mathrm{Ta}= & \text { level of crop damage of the } \\ & \text { treatment plot after insecticide } \\ & \text { application } \\ \mathrm{Tb}= & \text { level of crop damage of the } \\ & \text { treatment plot before insecticide } \\ & \text { application }\end{aligned}$

\section{RESULTS AND DISCUSSION}

Observation in the field indicated that the level of B. tabaci population fluctuated over time (Table 1.) This fluctuation may be not only affected by treatment applications, but also influenced by environmental factors. Fluctuations in population were thought to relate to the intensity of rainfall that varies during the experiment. B. tabaci population could decrease when high rainfall, whereas population increased when rainfall is low (Horowitz 1986). In addition, temperature also affects the ability of B. tabaci to survive, with an optimum temperature between 17$35^{\circ} \mathrm{C}$ (Bonato et al. 2006).

In general, the population of $B$. tabaci on BPMC (500 g a.i./l) treatment were significantly lower than control. On 21 DAP, the suppression of population B. tabaci that reached $50.0 \%$ was occurred in plots applied with BPMC (500 $\mathrm{g}$ a.i./l) at concentration of 2.25 and $3.00 \mathrm{ml} / \mathrm{l}$. Consistency of BPMC (500 g a.i./l) at concentration of 2.25 and $3.00 \mathrm{ml} / 1$ in reducing population of up to $50 \%$ also occurred at 28 and 35 DAP (Table 1).

The experiment results also showed that the suppression rate of population $B$. tabaci is correlated with the concentration of application. Increasing concentrations of BPMC caused the disease of insect population (500 $\mathrm{g}$ a.i./l) is followed by the decrease of the level of insect population lower. This pattern was rou- 
tinely discussed in observations. Table 1 showed that at concentration of 3.00 $\mathrm{ml} / \mathrm{l}$, population was lowest, then gradually increased with decreasing concentration, i.e. from $2.25,1.5$, and $0.75 \mathrm{ml} / \mathrm{l}$.
The Effect of BPMC (500 g a.i./l) application of in controlling $B$. tabaci seems to be associated with the occurrence of cowpea mild mottle virus (CMMV). Based on field observations, it appeared that symptoms of the CMMV disease clearly visible on the

Table 1. Effect of insecticide BPMC (500 g a.i./l) against imago population of $B$. tabaci

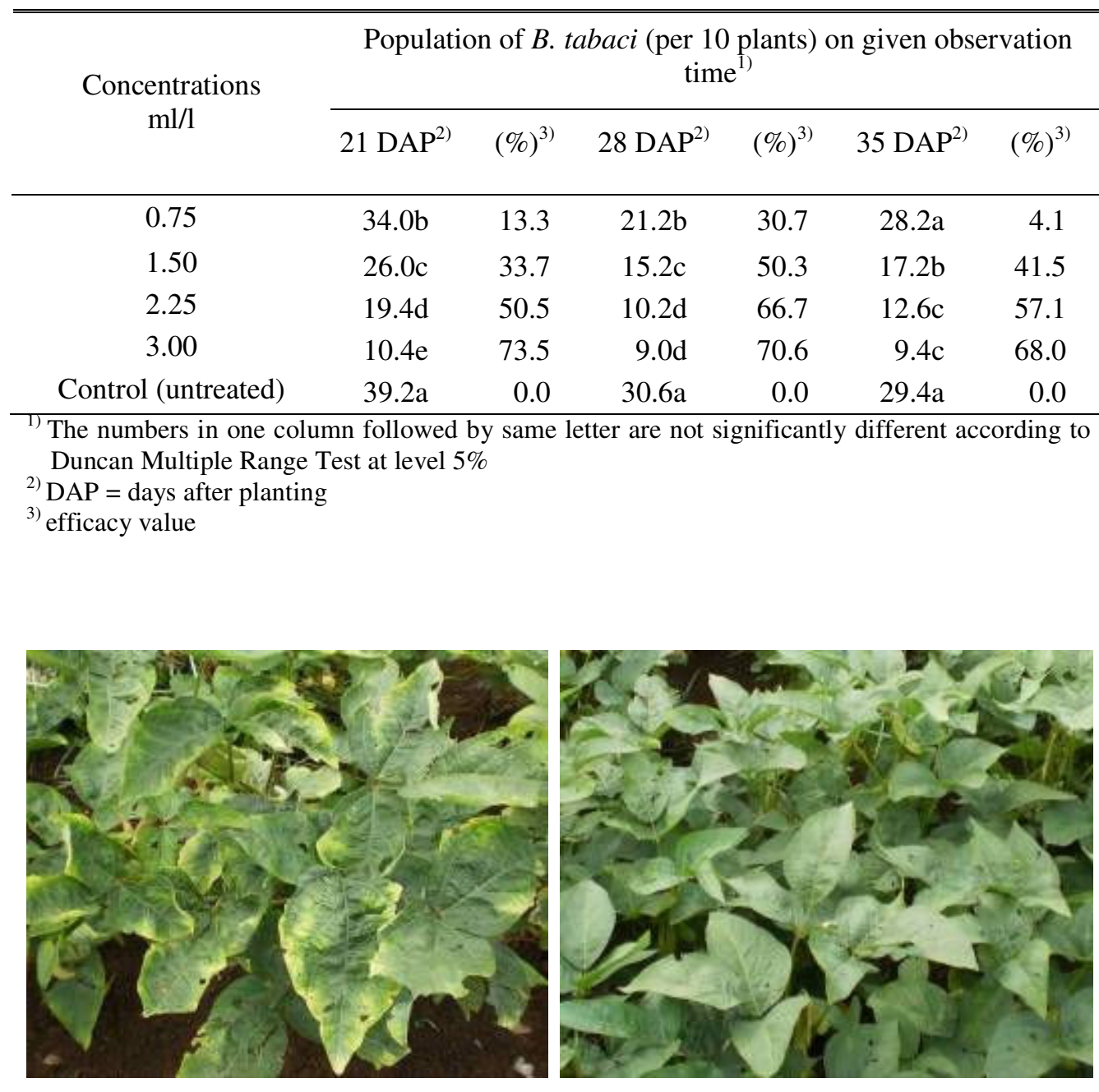

Figure 1. Soybean plants attacked by CMMV (left) and healthy plants (right) 
fifth observation. Infected soybean plants showed pale green in color, wrinkled of surface leaf, yellowish mosaic and irregular criss cross (Figure 1). Symptoms of disease vary depending on CMMV infected soybean cultivars (Mitsuro 2001). CMMV symptom was proven positive by NCMELISA test results as shown in Figure 2. NCM-ELISA test results showed that the leaf samples taken from the field randomly showed a positive reaction infected by CMMV.

Disease incidence of CMMV observed at 5 and 8 weeks after planting (WAP) showed varying value. Table 2 showed that the disease incidence in plots treated with BPMC (500 g a.i./l) was significantly smaller than control.
Disease incidence of plants applied with BPMC (500 g a.i./l) at concentration of 0.75 to $3.0 \mathrm{ml} / 1$ was no more than $3.2 \%$. While in control, until the eighth weeks of observation, the disease incidence reached $98.2 \%$. This result indicated that suppression of $B$. tabaci influenced to disease incidence of CMMV.

Based on the results of this study, the treatment of BPMC (500 g a.i./l) concentration was inversely proportional to the population and disease incidence of CMMV. Figure 3 showed that population of $B$. tabaci and disease incidence of CMMV was lower when the application concentration was increased.

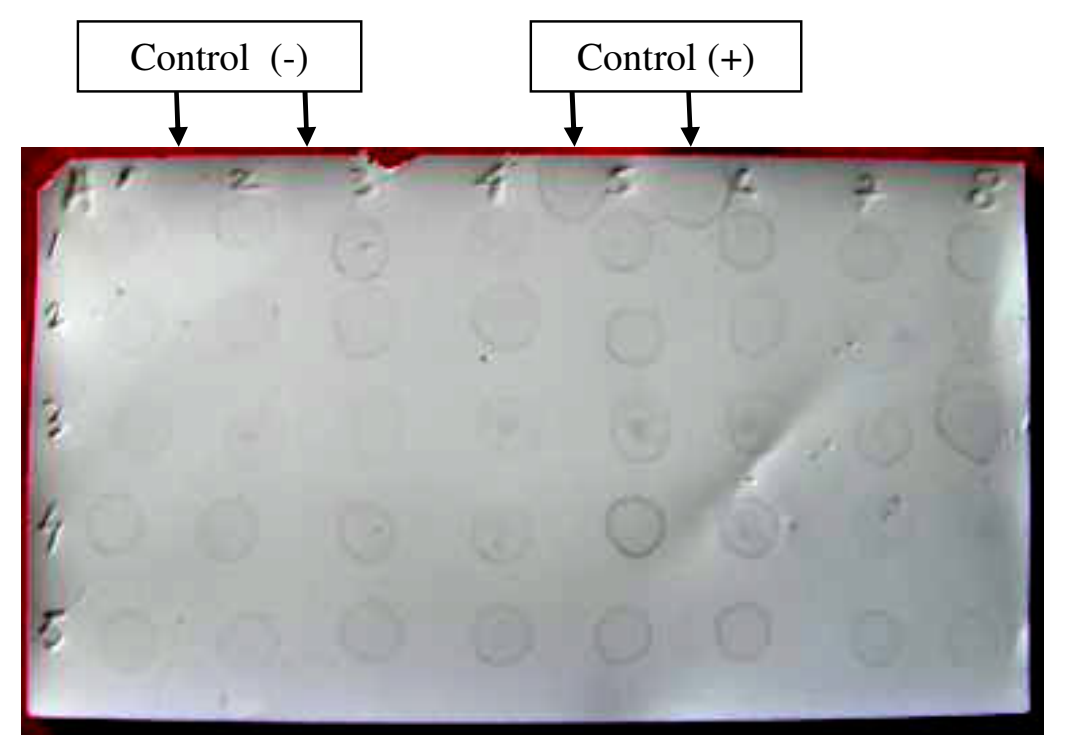

Column 1 to 8 were the leaf samples from each treatment Row 1 to 5 were the treatment Control (-) was the negative reaction of healthy leaf Control (+) was the positive reaction of the CMMV infected leaf

Figure 2. The result of CMMV detection using NCM-ELISA 
Table 2. Effect of insecticide BPMC (500 $\mathrm{g}$ a.i./l) on the disease incidence of CMMV

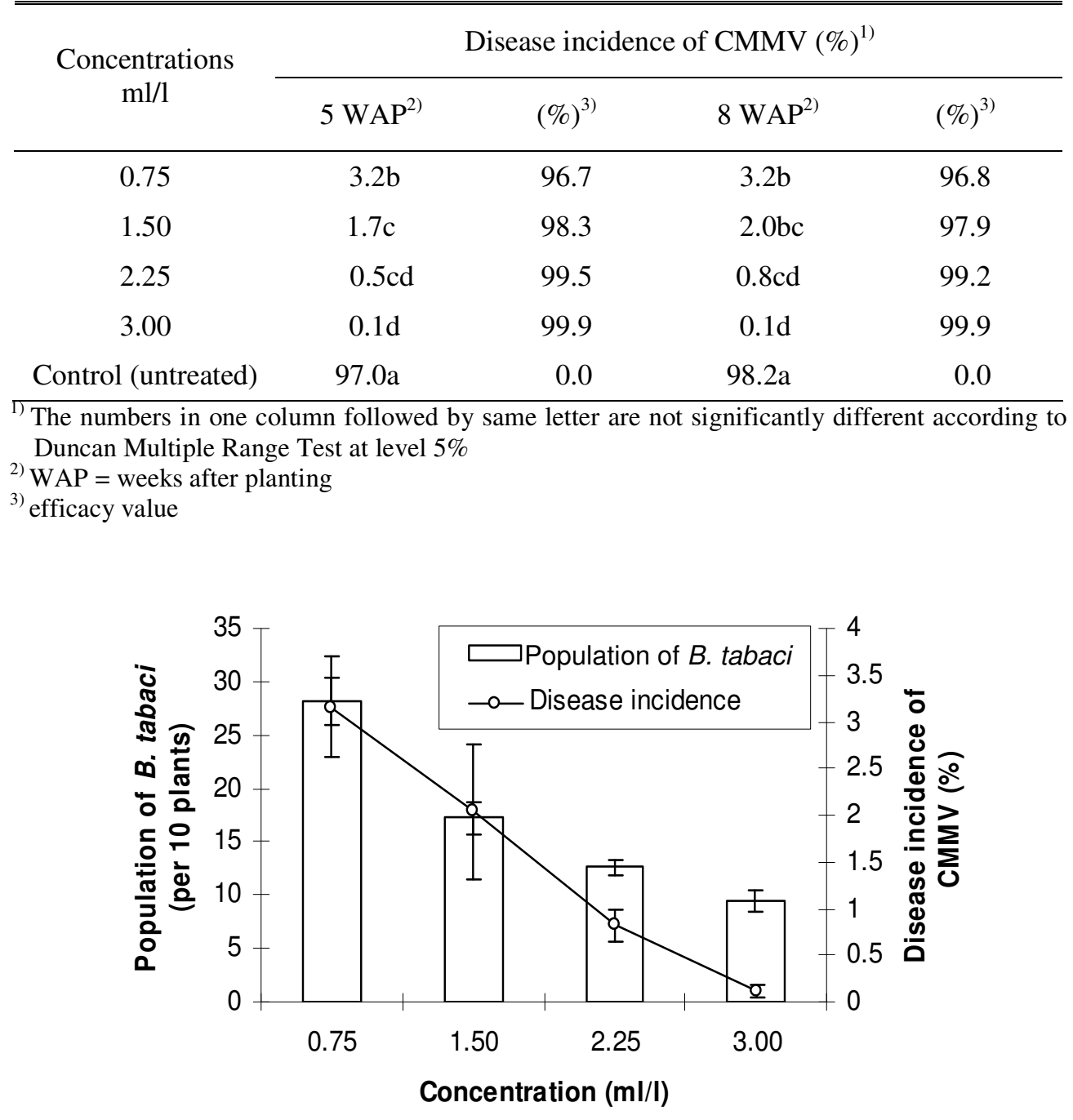

Figure 3. Relationship between the concentration of BPMC (500 g a.i./l) with a population of B. tabaci and the disease incidence of CMMV

CMMV is part of non-persistent viruses. In controlling non-persistent viruses, chemical is widely used. This is intended to suppress the population of $B$. tabaci which act as vectors or transmitters of the virus. Reduction on vector population will reduce the spread of viruses by insects. BPMC effectiveness in suppressing populations of $B$. tabaci is one way that proved effective in suppressing the disease incidence of CMMV. Several studies also showed that the spraying of insecticides such as cypermethrin, 
deltamethrin, permethrin, fanfalerate, disulfoton and acephate can reduce vector population and reduce or slow the spread of the virus (Asjes 1985 Atiri et al. 1987 Piron et al. 1988).

The effectiveness of insecticide BPMC in controlling the population of B. tabaci is caused by the disruption the nervous system and muscle of the insect. BPMC is an active ingredient of carbamates group that inhibit the production of insect acetylcholinesterase (IRAC 2010). The effectiveness of BPMC was proven reportedly effective in controlling some types of pests from other food commodities, for examples it was used to control Nilaparvata lugens, Leptocorisa oratorius, Hydrella philippina, Spodoptera litura, Empoasca sp., Helicoverpa armigera, Aphis sp., Valanga nigricornis, and Helopheltis sp. (Supriyatin 2000; Surachman and Suryanto 2007; BBPadi 2009; Baehaki 2011).

\section{CONCLUSION}

The application of BPMC (500 $\mathrm{g}$ a.i./l) reduced $B$. tabaci population. The suppression rate of $B$. tabaci population correlated with the concentration of BPMC application. Effect of BPMC application in controlling $B$. tabaci seems to be associated with the occurrence CMMV.

\section{ACKNOWLEDGMENTS}

The author thanks Narno for technical work in the field. Our Appreciation goes to PT. Biotis Agrindo, Indonesia that has sponsored the research and Indonesian Center for Agricultural Biotechnology and Genetic Resources Research and Development (ICABIOGRAD) which facilitated the research.

\section{REFERENCES}

Abbott WS. 1925. A method of computing the effectiveness of an insecticide. J. Econ. Entomol. 18:265-267.

Alegbejo MD. 2000. Whitefly transmitted plant viruses in Nigeria. $J$. Sustain. Agri. 17(2):99-109

Asjes CJ. 1985. Control of field spread of non-persistent viruses in flowerbulb crops by synthetic pyrethroid and pirimicarb insecticides and mineral oil. Crop Protection 4(4):485-493.

Atiri G, Thottapilly G, and Ligan D. 1987. Effect of cypermethrin and deltamethrin on the feeding behaviour of Aphis craccivora and transmission of cowpea aphidborne mosaic virus. Annals Appl. Biol. 110:455- 461.

Baehaki SE. 2011. Strategi fundamental pengendalian hama wereng batang coklat dalam pengamanan produksi padi nasional. $P e$ ngembangan Inovasi Pertanian 4(1):63-71.

BB Padi, 2009. Leptocorisa oratorius. http://bbpadi.litbang.deptan.go. 
id/index. php?option=com_cont ent $\&$ view $=$ article $\&$ id $=206 \% 3 \mathrm{~A}$ hama-walang-sangit -leptcorisaoratorius- $\&$ catid $=60 \% 3$ Ahamapadi $\&$ Itemid $=98 \&$ lang $=$ in [accessed in 30 November 2011].

Bonato O, Amandinelurette, Clairevidal, Jacquesfargues. 2006. Modelling temperature dependent bionomics of Bemisia tabaci (Qbiotype). Physiological Entomology 32(1):50-55

Gerling D, Motro U, Horowitz R. 1980. Dynamics of Bemisia tabaci (Gennadius) (Homoptera: Aleyrodidae) attacking cotton in the coastal plain of Israel. $B$. Entomol. Res. 70(2):213-219.

Harnoto, Iqbal A, dan Honma K. 1985. Hama kedelai. Di dalam: Petunjuk bergambar untuk identifikasi hama dan penyakit kedelai. Bogor: Pusat Penelitian dan Pengembangan Tanaman Pangan dan JICA. p 41-73.

Harnoto, Djuwarso T, dan Koswanudin D. 1993. Bioekologi dan pengendalian lalat kacang Ophiomyia phaseoli. Di dalam: M. Syam, dkk. (eds.) Prosiding Simposium Penelitian Tanaman Pangan III. Pusat Penelitian dan Pengembangan Tanaman Pangan. Bogor: 23-25 Agustus 1993. Bogor: Pusat Penelitian dan Pengembangan Tanaman Pangan. $\mathrm{p}$ 1373-1382.

Henderson CF and Tilton EW. 1955.

Tests with acaricides against the brow wheat mite. J. Econ. Entomol. 48:157-161.

Horowitz AR, Podoler H, Gerling D. 1984. Life table analysis of the tobaco whitefly Bemisia tabaci (Gennadius) in cotton fields in Israel. Acta Oecol. 5:221-233.

Horowitz AR. 1986. Population dynamics of Bemisia tabaci (Gennadius) with special emphasis on cotton fields. Agric. Ecol. Environ. 17:37-47.

IRAC. 2010. Mode of Action Classification. $2^{\text {nd }}$ ed. $20 \mathrm{pp}$.

Iwaki M, Meearkom P, Prommin M, Honda Y, and Hibi T. 1983. Whitefly transmission and some properties of Cowpea mild mottle virus on soybean in Thailand. Plant Disease 66:365-368.

Lazarovits, G, Zutra D, Bar-Joseph M. 1989. Enzyme linked immunosorbent assay on nitrocellulose membranes (dot- ELISA) in serodiagnoses of plant pathogenic bacteria. Can. J.Microbiol. 33:98-103.

Mitsuro K. 2001. Virus diseases of soybean in southeast Asian countries. Plant Protection, 2001-6. 4 pp.

Muniyappa V. and Reddy DVR. 1982. Transmission of Cowpea mild mottle virus by Bemisia tabaci in non-persistent manner. Plant Disease 67:391-393.

Nomikou, M, Janssen A, Schraag R, Sabelis MW. 2000. Phytoseiid predators as potential biological control agent for Bemisia tabaci. Exp. Appl. Acarol. 25(2):271291.

Pirone TP, Raccah B, and Madden LV. 1988. Suppression of aphid colonization by insecticides: effect on incidence of potyvirus on 
tobacco. Plant Disease 72:350353.

Saleh N, Candrawati M, Hadiastono T, Rasminah S, Baliadi Y, dan Hadi M. 2005. Tingkat ketahanan empat varietas unggul kacang tanah terhadap infeksi Cowpea mild mottle virus. Di dalam: $P e$ ningkatan Produksi kacangkacangan dan Umbi-umbian Mendukung Kemandirian Pangan. Bogor: Puslitbangtan. p 499510.

Saleh N, Baliadi Y, Martosudiro M, dan Indrawati T. 2004. Evaluasi ketahanan empat varietas unggul baru kedelai terhadap infeksi Cowpea mild mottle virus. Dalam Kinerja Penelitian mendukung agribisnis kacang-kacangan dan umbi-umbian. Bogor: Puslitbangtan. p 461-470.
Saleh N, Yuliantoro B, and Horn NM. 1989. Cowpea mild mottle virus isolated from naturally infected Arachis hypogaea L. Penelitian Palawija 4:32-35.

Simón B, Cenis JL, Demichelis S, Rapisarda C, Cacigli P, Bosco D. 2003. Survey of Bemisa tabaci (Hemiptera: Aleyrodidae) biotypes in Italy with the description of a new biotype (T) from Euphorbia characias. B. Entomol. Res. 93(2):259-264.

Surachman E, Suryanto WA. 2007. Hama Tanaman Pangan, Hortikultura, dan Perkebunan Masalah Dan Solusinya. Yogyakarta: Kanisius Press. p 111

Supriyatin 2000. Pengaruh insektisida terhadap hama kacang tanah dan musuh alaminya. Eds. Khusus Balitkabi, No.16. 